Jurnal Indonesia Sosial Teknologi: p-ISSN: 2723 - 6609

e-ISSN : 2745-5254

Vol. 2, No. 5 Mei 2021

\title{
PENGARUH LOCUS OF CONTROL TERHADAP KINERJA USAHA DENGAN ORIENTASI PASAR SEBAGAI VARIABEL MODERASI
}

\author{
Fahmi Abdullah \\ Prodi Manajemen STIE Yadika Bangil \\ Email: fahmi@stie-yadika.ac.id
}

\begin{abstract}
The trading conditions at the Porong flea market have increased every year, this can be seen from the increasing number of traders in the flea market and at this time trading facilities are also increasingly adequate. This study aims to determine the effect of locus of control on business performance and to determine the moderating effect of market orientation on the effect of locus of control on business performance. The analytical tool to test the hypothesis using SPSS 16.0. The sample in this study was 82 traders in the flea market in Porong District. The first regression equation in this study is as follows: $Y=1.294+0.671 X 1$, the results of the first hypothesis test show that the hypothesis is accepted, meaning that locus of control has a significant effect on business performance, while the second regression equation is $Y=3.997+0.310 \mathrm{ZX} 1+0.042 \mathrm{ZX} 2+0.026$ AbsZX1-ZX2 for the second hypothesis test, the result is rejected, meaning that market orientation is not able to moderate the effect of locus of control on business performance, from the research results it states that market orientation is homologous moderation, because b2 and b3 have no significant effect.
\end{abstract}

Keyword: Locus of control, market orientation, business performance and Homologiser Moderation

\begin{abstract}
Abstrak
Kondisi perdagangan di pasar loak Porong setiap tahunnya mengalami peningkatan, hal ini dapt dilihat dari semakin banyaknya jumlah pedagang di pasar loak dan pada saat ini juga fasilitas berdagang juga semakin memadai. Penelitian ini bertujuan untuk mengetahui pengaruh locus of contorl terhadap kinerja usaha dan mengetahui efek moderasi orientasi pasar pada pengaruh locus of control terhadap kinerja usaha. Alat analisis untuk menguji hipotesis menggunakan SPSS 16.0 sampel dalam penelitian ini adalah 82 pedagang di pasar loak Kecamata Porong. persamaan regresi pertama pada penelitian ini sebagai berikut: $\mathrm{Y}=1,294+0,671 \mathrm{X} 1$, hasil uji hipotesa kesatu menunjukkan hipotesis diterima, artinya locus of control berpengaruh signifikan terhadap kinerja usaha, sedangkan persamaan regresi kedua adalah $\mathrm{Y}=3,997+0,310 \mathrm{ZX} 1+0,042 \mathrm{ZX} 2+0,026$ AbsZX1-ZX2 untuk uji hipotesis kedua, hasilnya ditolak artinya orientasi pasar tidak mampu memoderasi pengaruh locus of control terhadap kinerja usaha, dari hasil penelitian menyebutkan bahwa orientasi pasar merupakan homologiser moderation, karena b2 dan b3 samasama tidak signifikan pengaruhnya.
\end{abstract}


Kata kunci: Locus of control; Orientasi pasar; kinerja usaha dan Homologiser Moderation

\section{Pendahuluan}

Munculnya mini market di Indonesia sangat menjamur di Indonesia, khususnya di Jawa Timur, keberadaannya yang berada di tempat-tempat strategis, tempatnya yang bersih dan nyaman, penawaran diskon untuk produk-produk tertentu membuat konsumen tertarik untuk membelanjakan uangnya, Pertumbuhan pasar pusat perbelanjaan dan pasar modern yang semakin besar telah mengancam keberadaan dan kelangsungan hidup pasar tradisional. (Pramudyo, 2014) Namun keberadaan mini market tidak membuat keberadaan pasar tradisional terancam, terbukti menurut data BPS tercatat terdapat 1.823 unit pasar tradisional yang tersebar di seluruh Jawa Timur. Di Sidoarjo tepatnya di Kecamatan Porong terdapat pasar tradisional yang dijadikan tempat kulakan, disamping terdapat berbagai jualan produk sayuran, buah-buahan, bumbu-bumbu dapur, keberadaan pasar loak di pasar porong menjadi daya tarik tersendiri bagi pencari barang-barang bekas. Produk yang ditawarkan di pasar loak harganya murah, karena barangnya bekas pakai, disamping itu produk yang dijual di barang bekas seringkali menjual produk yang unik. Pasar tradisional sebagai sarana belanja bagi masyarakat, mempunyai salah satu ciri positif yang mengharuskan interaksi dengan bentuk kegiatan tawar menawar antara pembeli dan penjual. (Sasanto, 2010)

Keberadaan pasar loak porong, awalnya berada di daerah Stasiun Porong dengan penjual yang menggelar alas untuk berjualan seadanya tanpa adanya kios/tempat dengan jumlah penjual 27 pedagang, namun karena ada peristiwa lumpur lapindo, keberadaan pasar loak porong pindah mengikuti pasar induk baru porong. Setelah pindah ke tempat yang baru, keberadaan pasar loak porong semakin eksis, hal ini dibuktikan dengan jumlah pedagang yang menjadi lebih banyak dengan jumlah lebih dari 100 pedagang loak, disamping itu sekarang sudah ada organisasi khusus pedagang loak di pasar porong dengan nama "paguyuban pasar loak porong". Bahkan pemerintah daerah menfasilitasi para pedagang dengan membangun fasilitas pasar loak dengan membangun lapak/kios bagi pedagang, dengan fasilits tersebut membuat pedagang dan pengunjung lebih nyaman dalam berbelanja (Safitri et al., 2020). Sistem perdagangan juga akan mengalami perubahan. Hal ini membuat para produsen terpacu untuk meningkatkan produktivitas dan kreatifvitas agar dapat bertahan menghadapi perubahan pasar. (Wijayanti, 2019)

Melihat kondisi tersebut menunjukkan adanya kinerja usaha yang baik bagi pedagang di pasar loak porong (Aslam, 2012). Keberadaan produk baru dengan harga beragam pada saat ini tidak mampu mengurangi animo masyarakat untuk membeli produk bekas, pelanggan kini semakin kritis terhadap toko yang akan dimasukinya. Mereka kini lebih terpelajar, lebih mempertimbangkan harga, cepat habis kesabarannya, dan tidak mudah memaafkan. (Masyhuri, 2017) hal ini terbukti dengan semakin banyaknya pedagnag dan pengunjung di pasar loak porong. Semakin berkembangnya bisnis barang bekas ini tidak lepas dari sifat locus of control yang dimiliki oleh 
pedagang, karena locus of control berkaitan dengan kemampuan yang dimiliki oleh pedagang dalam menjalankan usahanya.

Hasil inkonsistensi studi empiris berkaitan dengan pengaruh locus of control terhadap kinerja usaha, Beberapa penelitian mempunyai masing - masing pandangan dan hasil, locus of control tidak berpengaruh signifikan terhadap kinerja usaha (Purnomo, 2010), locus of control berpengaruh signifikan terhadap kinerja (AYUDIYATI, 2010) memunculkan celah penelitian, celah penelitian ini diisi oleh variabel orientasi pasar, 799imple799 pemilihan orientasi pasar karena tidak adanya hubungan antara locus of control dengan orientasi pasar, disamping itu adanya studi empiris yang menunjukkan adanya hubungan antara orientasi pasar dengan kinerja usaha, diantaranya penelitian menunjukkan orientasi pasar berpengaruh signifikan terhadap kinerja usaha, menjadi 799imple799 memasukkan variabel orientasi pasar sebagai variabel moderasi (Susanto, 2012).

\section{Metode Penelitian}

Populasi dalam penelitian ini adalah seluruh pedagang di pasar loak Porong berjumlah 103, adapun deskripsi pedagang loak pasar barang dapat dilihat pada 799impl berikut:

Tabel 1. Pedagang loak pasar porong

\begin{tabular}{|c|c|c|}
\hline No. & Tempat & Jumlah \\
\hline 1. & Blok A-a Gg.1 & 21 Pedagang \\
\hline 2. & Blok A-a Gg.2 & 14 Pedagang \\
\hline 3. & Blok A-a Gg.3 & 7 Pedagang \\
\hline 4. & Blok B-b Gg.3 & 9 Pedagang \\
\hline 5. & Blok B-b Gg.4 & 20 Pedagang \\
\hline 6. & Blok B-b Gg.5 & 16 Pedagang \\
\hline 7. & Blok PKL & 10 Pedagang \\
\hline 8. & Blok Warung & 6 Pedagang \\
\hline & Total & 103 Pedagang \\
\hline
\end{tabular}

Sumber: paguyuban pasar loak Porong, 2020.

Adapun sampel yang digunakan adalah 799imple random sampel, teknik pengambilan sampel berdasar pada berapa banyak kuesioner yang diisi dan dikembalikan ke peneliti, dalam hal ini peneliti menyebar 103 kuesioner, dari 103 kuesioner yang disebar dikembalikan sebanyak 87 kuesioner dan dari 87 yang diisi dengan benar sejumlah 82 kuesioner, jadi dalam penelitian ini sampel sebesar 82 responden. 
Tabel 2. Variable, indicator dan Item

\begin{tabular}{|c|c|c|}
\hline Variabel & Indikator & Item \\
\hline \multirow[t]{2}{*}{$\begin{array}{l}\text { Locus of } \\
\text { contro (X1) }\end{array}$} & $\begin{array}{l}\text { 1. Internal locus } \\
\text { of } \\
\text { Control }\end{array}$ & $\begin{array}{l}\text { 1. Segala yang dicapai individu dalam } \\
\text { hidup adalah hasil dari usaha yang } \\
\text { telah dilakukan sendiri, } \\
\text { 2. Menjadi wirausaha sangat tergantung } \\
\text { kemampuan saya, } \\
\text { 3. Keberhasilan yang terjadi adalah hasil } \\
\text { dari kerja keras saya sendiri, } \\
\text { 4. Apa yang diperoleh bukan karena } \\
\text { keberuntungan, } \\
\text { 5. Saya mampu menentukan apa yang } \\
\text { akan terjadi dalam hidup saya, } \\
\text { 6. Hidup saya ditentukan oleh tindakan } \\
\text { saya sendiri, } \\
\text { 7. Kegagalan yang saya alami akibat dari } \\
\text { perbuatan saya sendiri }\end{array}$ \\
\hline & $\begin{array}{l}\text { 2. External locus of } \\
\text { Control }\end{array}$ & $\begin{array}{l}\text { 1. Kegagalan adalah akibat } \\
\text { ketidakmujuran, } \\
\text { 2. Membuat perencanaan yang terlalu } \\
\text { jauh ke depan adalah pekerjaan sia-sia, } \\
\text { 3. Apa yang terjadi dalam hidup } \\
\text { sebagian besar ditentukan oleh orang } \\
\text { lain yang memiliki kekuasaan, } \\
\text { 4. Kesuksesan dicapai semata-mata } \\
\text { karena faktor nasib }\end{array}$ \\
\hline \multirow[t]{2}{*}{$\begin{array}{l}\text { Orientasi } \\
\text { pasar (X2) }\end{array}$} & $\begin{array}{l}\text { 2. Orientasi } \\
\text { pelanggan }\end{array}$ & $\begin{array}{l}\text { 1. Kebutuhan (needs) pelanggan dapat } \\
\text { diketahui dengan bervariasinya suatu } \\
\text { produk } \\
\text { 2. Pilihan (preferences) pelanggan dapat } \\
\text { diketahui denga melihat beberapa } \\
\text { pilihan produk. } \\
\text { 3. Komplain (complains) yang dapat } \\
\text { diketahui dengan seberapa intensitas } \\
\text { para pelapak memberikan tanggapan } \\
\text { terkait dengan pertanyaan dan keluhan } \\
\text { dari konsumen. }\end{array}$ \\
\hline & 2. Orientasi pesaing & $\begin{array}{l}\text { 3. Mengetahui produk yang banyak laku } \\
\text { di pasaran } \\
\text { 4. Mengetahui harga perolehan barang } \\
\text { bekas sesuai harga pasaran } \\
\text { 5. Mengetahui harga jual barang sesuai } \\
\text { dengan yang dijual pesaing. }\end{array}$ \\
\hline
\end{tabular}




\begin{tabular}{lll}
\hline 6. Koordinasi & $\begin{array}{l}\text { 1. Adanya pemberian informasi tentang } \\
\text { manfaat produk kepada pembeli } \\
\text { tentang produk yang dijual oleh } \\
\text { pelapak }\end{array}$ \\
& interfungsional & $\begin{array}{l}\text { 2. Pemberian informasi tentang } \\
\text { kekurangan produk yang dijual }\end{array}$ \\
\hline Kinerja & 1. Pertumbuhan & $\begin{array}{l}\text { 1. Ada peningkatan jumlah penjualan } \\
\text { usaha }(\mathrm{Y})\end{array}$ \\
\cline { 2 - 4 } & penjualan & 2. Ada peningkatan keuntungan \\
& $\begin{array}{l}\text { 2. Pertumbuhan } \\
\text { usaha }\end{array}$ & $\begin{array}{l}\text { 1. Bertambahnya jumlah karyawan } \\
\text { 2. Pemasaran sudah secara online. }\end{array}$
\end{tabular}

Sumber: Hasil pengolahan data, 2020

\section{Hasil dan Pembahasan}

Karakteristik responden berdasar jenis kelamin menunjukkan responden berjenis laki-laki ada 72 orang atau $87,8 \%$ dan jenis kelamin perempuan ada 10 orang atau 12,2\%. Hal ini menunjukan responden laki-laki lebih banyak dari responden perempuan. Umur responden $(<30)$ atau kurang dari 30 tahun yaitu sebanyak 1 orang atau $1,2 \%$, diikuti dengan umur ( $>50)$ atau lebih dari 50 tahun sebanyak 42 orang atau $51,2 \%$, diikuti dengan umur (30-40) atau 30 sampai 40 tahun sebanyak 14 orang atau $17,1 \%$, diikuti dengan umur (40-50) atau 40 sampai 50 tahun sebanyak 25 orang atau $130,5 \%$, Dari data tersebut dapat disimpulkan bahwa responden yang berumur $(>50)$ lebih dari 50 tahun yaitu sebanyak 42 orang atau 51,2\% lebih banyak dari keseluruhan responden. Pendidikan Terakhir responden yang berasal dari lulusan Pesantren sebanyak 7 orang atau 8,5\%, SD sebanyak 12 orang atau 14,6\%, SMA sebanyak 44 orang atau 53,7\%, SMK sebanyak 3 orang atau 3,7\%, SMP sebanyak 16 orang atau 19,5\%. Dari data tersebut dapat disimpulkan bahwa sebagian besar responden berasal dari lulusan SMA sebanyak 44 orang atau 53,7\% dari dari total responden. Lama berdagang responden $(<10)$ atau kurang dari 10 tahun yaitu sebanyak 6 orang atau $7,3 \%$, diikuti dengan lama berdagang ( $>30$ ) lebih dari 30 tahun sebanyak 30 orang atau $36,6 \%$, diikuti dengan lama berdagang (15-30) atau 15 sampai 30 tahun sebanyak 46 orang atau 56,1\%, Dari data tersebut dapat disimpulkan bahwa lama berdagang responden (15-30) atau 15 sampai 30 tahun yaitu sebanyak 46 orang atau 56,1\% lebih banyak dari keseluruhan lama berdagang responden.

Uji Validitas dan reliabilitas

1. Uji Validitas

Tabel 3. Hasil uji validitas

\begin{tabular}{lccc}
\hline Indikator & r hitung & r tabel & Keterangan \\
\hline $\mathrm{X} 1.1 .1$ & .636 & 0,2213 & VALID \\
\hline $\mathrm{X} 1.1 .2$ & .646 & 0,2213 & VALID \\
\hline $\mathrm{X} 1.1 .3$ & .662 & 0,2213 & VALID \\
\hline
\end{tabular}




\begin{tabular}{llll}
\hline $\mathrm{X} 1.1 .4$ & .629 & 0,2213 & VALID \\
\hline $\mathrm{X} 1.1 .5$ & .601 & 0,2213 & VALID \\
\hline $\mathrm{X} 1.1 .6$ & .673 & 0,2213 & VALID \\
\hline $\mathrm{X} 1.1 .7$ & .683 & 0,2213 & VALID \\
\hline $\mathrm{X} 1.2 .1$ & .671 & 0,2213 & VALID \\
\hline $\mathrm{X} 1.2 .2$ & .535 & 0,2213 & VALID \\
\hline $\mathrm{X} 1.2 .3$ & .445 & 0,2213 & VALID \\
\hline $\mathrm{X} 1.2 .4$ & .431 & 0,2213 & VALID \\
\hline $\mathrm{X} 2.1 .1$ & .906 & 0,2257 & VALID \\
\hline $\mathrm{X} 2.1 .2$ & .770 & 0,2257 & VALID \\
\hline $\mathrm{X} 2.1 .3$ & .903 & 0,2257 & VALID \\
\hline $\mathrm{X} 2.2 .1$ & .787 & 0,2257 & VALID \\
\hline $\mathrm{X} 2.2 .2$ & .910 & 0,2257 & VALID \\
\hline $\mathrm{X} 2.2 .3$ & .802 & 0,2257 & VALID \\
\hline $\mathrm{X} 2.3 .1$ & .891 & 0,2257 & VALID \\
\hline $\mathrm{X} 2.3 .2$ & .882 & 0,2257 & VALID \\
\hline $\mathrm{Y} 1.1$ & .481 & 0,2199 & VALID \\
\hline $\mathrm{Y} 1.2$ & .627 & 0,2199 & VALID \\
\hline $\mathrm{Y} 2.1$ & .673 & 0,2199 & VALID \\
\hline $\mathrm{Y} 2.2$ & .552 & 0,2199 & VALID \\
\hline
\end{tabular}

Sumber:hasil pengolahan data, 2020

2. Uji Reliabilitas

Tabel 4. Hasil uji reliabilitas

\begin{tabular}{lcl}
\hline Variabel & Cronbach's alpha & Keterangan \\
\hline Locus of control (X1) & 0,885 & Reliabel \\
\hline Orientasi pasar (X2) & 0,963 & Reliabel \\
\hline Kinerja usaha (Y) & 0,776 & Reliabel \\
\hline
\end{tabular}

3. Persamaan Regresi sederrhana

Persamaan regresi sederhana dalam penelitian ini $\mathrm{Y}=1,294+0,671 \mathrm{X} 1$, Untuk uji Hipotesis 1 yang menyatakan locus of control (X1) berpengaruh signifikan terhadap kinerja usaha, dapat dilihat dari nilai signifikasinya, dalam tabel coefficient diatas, nilai signifikasi sebesar 0,000 (dibawah 0,05) artinya Hipotesis 1 diterima atau bahwa locus of control berpengaruh signifikan terhadap kinerja usaha. Dari tabel ANOVA dapat diketahui nilai signifikasi sebesar 0,00 (dibawah 0,05) artinya persamaan regresi pada regresi sederhana dapat digunakan untuk memprediksi. (Pradana et al., 2019) Sedangkan nilai Rsquare dalam tabel model summary sebesar 0,364 artinya variabel locus of control mempengaruhi kinerja keuangan sebesar $36,4 \%$

4. Persamaan Regresi Berganda

Persamaan regresi pada persamaan ini adalah $\mathrm{Y}=3,997+0,310 \mathrm{ZX} 1+0,042 \mathrm{ZX} 2+$ 0,026 AbsZX1-ZX2. Uji Hipotesis kedua H2 : orientasi pasar mampu memoderasi 
pengaruh locus of control terhadap kinerja keuangan, dapat dilihat dari nilai signifikasi pada AbsX1-X2, dapat diketahui nilai signifikasi pada variabel AbsX1X2 sebesar 0,760 (diatas 0,05) artinya Hipotesis kedua ditolak atau orientasi tidak mampu memoderasi pengaruh locus of control terhadap kinerja keuangan (Asnawawi, 2020). Melihat nilai signifikasi dari masing-masing variabel dapat diketahui bahwa persamaan diatas adalah merupakan homologiser moderation, karena b2 dan b3 sama-sama tidak signifikan pengaruhnya.

\section{Kesimpulan}

Berdasarkan penelitian dan analisa yang dilakukan pada bab sebelumnya, maka kesimpulan dalam penelitian menyebutkan bahwasannya locus of control berpengaruh signifikan terhadap kinerja usaha, hasilnya diterima, artinya bahwa locus of control berpengaruh signifikan terhadap kinerja usaha selanjutnya orientasi pasar mampu memoderasi pengaruh locus of control terhadap kinerja keuangan, hasilnya hipotesis ditolak, artinya variabel orientasi pasar tidak mampu memperkuat atau memperlemah pengaruh locus of control terhadap kinerja keuangan 


\section{Bibliography}

Aslam, M. (2012). Mobilitas sosial pedagang pasar induk Puspa Agro di desa Jemundo kecamatan Taman kabupaten Sidoarjo. IAIN Sunan Ampel Surabaya.

Asnawawi, A. (2020). Pengaruh Role Conflict, Self Efficacy, dan Tekanan Ketaatan terhadap Perilaku Etis Auditor dengan Religiusitas sebagai Variabel Moderating (Studi pada Kantor Inspektorat Provinsi Sulawesi Selatan). Universitas Islam Negeri Alauddin Makassar.

Pradana, G. A. K., Kusuma, I. G. E. A., \& Rahmadani, D. A. (2019). Pengaruh Independensi, Locus Of Control, Kompleksitas Tugas Dan Orientasi Tujuan Terhadap Kinerja Auditor. JSAM (Jurnal Sains, Akuntansi Dan Manajemen), 1(4), 489-504.

Safitri, D., Mubyarto, N., \& Fielnanda, R. (2020). Analisis Dampak Relokasi Pasar Tradisional Terhadap Pendapatan Pedagang Sebelum Dan Sesudah Relokasi (Studi Dipasar Angso Duo). UIN Sulthan Thaha Saifuddin Jambi.

Susanto, P. (2012). Pengaruh Orientasi Pasar Pada Kinerja Perusahaan Kecil. Jurnal Kajian Manajemen Bisnis, 1(2).

Ayudiyati, S. E. (2010). Analisis Pengaruh Locus Of Control Terhadap Kinerja Dengan Etika Kerja Islam Sebagai Variabel Moderating (Studi Pada Karyawan Tetap Bank Jateng Semarang).

Masyhuri, M. (2017). Analisis Dampak Keberadaan Pasar Modern Terhadap Pasar. Jurnal Akuntansi dan Pendidikan.

Pramudyo, A. (2014). Menjaga Eksistensi Pasar Tradisional Di Yogyakarta. Jurnal Bisnis, Manajemen, dan Akuntansi,.

Purnomo, R. (2010). Pengaruh Kepribadian, Self-Efficacy, Dan Locus Of Control Terhadap. Jurnal Bisnis dan Ekonomi (JBE), 144 - 160.

Sasanto, R. (2010). Identifikasi Karakteristik Pasar Tradisional Di Wilayah. Jurnal PLANESA.

Wijayanti, M. (2019). Hubungan Determinasi Diri Dengan Motivasi. Jurnal Kognisia. 